\title{
Conventional Educational with Indoor and Outdoor Modules on Disaster Preparedness in High School Students in Tomohon
}

\author{
Rolly Harvie Stevan Rondonuwu, Monica Tandiayuk, Dorce Sisfiani Sarimin \\ rollyhsr@yahoo.com
}

\begin{abstract}
Indonesia is one of the countries that natural disasters are pretty much like floods, landslides, earth spices, volcanic eruptions, tsunamis. Increased volcanic activity in Indonesia volcanoes enables their potential in some areas. The disaster occurred in the community in need for good handling of disaster management, given that it comes unexpectedly, for many things that must be prepared carefully, including education on disaster management interventions. This module is a quasi experimental one group pretest-posttest. This module is indoor and outdoor + indoor modules for disaster preparedness in students in volcanoes in Tomohon, North Sulawesi. In this design high school students are given a pretest before being educated to know the initial state, and after the posttest given further education will be known whether there is a difference between the value of the pretest and posttest. The population was all high school students at Lokon, and the sample was grade 10 of 60 people, was conducted in September 2016. Results showed experimental groups of students' learning outcomes better than the control group. The average value of the student experimental posttest group (73.27) was higher than the average value posttest control group (66.17). There is a difference score in the group given indoor intervention module with the intervention of the indoor-outdoor module, with 0:00. (T idenpendent test). Based on the results of the study concluded that there are differences in knowledge between students taught by indoor learning by using indoor + outdoor learning.
\end{abstract}

Keywords: modules indoor, indoor module + oudoor

\section{INTRODUCTION}

Disaster is an event or series of events that threatens and disrupts people's lives caused by both natural factors and / or non-natural and human factors, resulting in fatalities, environmental damage, property losses and psychoogical impact (Law No. 24 of 2007).

Indonesia is one of the countries that experienced quite a lot of natural disasters such as floods, landslides, earth spices, volcanic eruptions, tsunamis. This is due to the location of Indonesia at the confluence of the Eurasian, Indo-Australian and Pacific plates. Long-term plate encounters cause the release of energy that produces disasters. Indonesia is on the "The Ring of Fire" (fire ring), which is the active volcano chain in the world. Therefore the number of volcanoes in Indonesia around 129 of them have a history of severe eruptions (BNPB 2010).

The increase in volcanic volcanic activity in Indonesia allows for potential eruptions in some areas, for which the government controls volcanic activity in collaboration with the Center for Volcanology and Geological Disaster Mitigation), in addition to increasing alertness and preparedness for volcanic disasters. (Zakaria 2008).

Fast, appropriate, effective, efficient, integrated and accountable coordination and handling are needed in disaster management so that the impact can be reduced. In disaster management, especially in the emergency response phase, knowledge about disaster management is urgently needed (Alexander 2009).

Miller 2014 conducted a study on the effect of giving simulations and education on community preparedness, suggesting that educational and simulation interventions were very effective in the respondents where there was an increase in knowledge and skills in disaster management for the respondents studied. Meanwhile, according to Russell 1970, disaster management will be more effective if preventive efforts are carried out, thereby minimizing casualties and making the community more responsive.

Margaret 2010 in her research titled The Evidence Base for Effectiveness of Preparedness Training: A Retrospective Analysis suggests that training programs are the basis needed to train participants' roles and responses to emergencies.

Hochrainer 2010, said that disasters can significantly reduce a country's economy. By using ARIMA analysis techniques on 225 events / events of natural disasters, it was concluded that within 5 years after the natural disaster, the economy slowly declined. Because disasters reduce the productivity of the production sectors.

The community needs to be given attention so that they are always prepared to face disasters, and be able to be empowered. One way that can be done is to provide education and simulation to the younger generation group through high school students about disaster preparedness.

Vol. XIV No. 1, Juni 2019

DOI: https://doi.org/10.32382/medkes.v14i1.708 
Community empowerment is one of the preventive ways to anticipate the impact that has taken place. Empowerment can be started from community institutions, especially young people as the next generation who will someday face disaster. As an empirical study of the existence of the province of North Sulawesi which is surrounded by mountains and there are active volcanoes, especially in Tomohon, namely Mount Lokon. In addition, there is a lack of understanding of the community, especially the younger generation, about disasters and how to deal with disasters.

The purpose of this study was to determine the effectiveness of the educational program using conventional indoor modules compared to indoor + outdoor modules on volcanic disaster preparedness in high school students in Tomohon City, North Sulawesi.

\section{METHODS}

The research design in this study was Quasi experiment one group pre-post-test (Sugiyono 2010). In this design high school students are given a pretest before being given education to find out the initial condition, and posttest after being given further education it will be known whether there is a difference between thescores pretest and posttest

Population is the target or unit where a study will be carried out, so that it can get an overview for the application of a study (Dharma, 2011). In this study the population were all Lokon high school students.

Samples are the smallest units in an affordable population group where researchers will collect data, observations / measurements on this unit (Dharma, 2011). The sampling technique that the researchers used in this study was by consecutive sampling technique, namely by selecting all respondents who met and fulfilling the selection criteria, until the desired number of samples was fulfilled. Patient inclusion criteria: Students who sit in 10th grade, physically healthy, Willing to take time to follow the training.

This research was conducted at Lokon Tomohon High School in September 2016.

\section{RESULTS}

This study was conducted in two classes of $X$ in Lokon Tomohon High School. The control class was given treatment using themethod Indoor learning, while the experimental class was treated using themethod Indoor +outdoor learning. The control group consisted of 30 students, and the experimental group consisted of 30 students.

\section{Data Normality Test}

Before the test is carried out, the researcher conducts data normality analysis test as follows:

Data normality test using komolgorov-smirnov control group pre test score ( $p$ value 0.100$)$ post test ( $p$ value 0.200 ) intervention group score / indoor outdoor module pre test ( $p$ value 0.71 ) and post test ( $p$ value 0.097 ) $p$ value more than $\alpha 0.05$, so the data is normally distributed.

The mean difference before and after intervention using conventional modules is Pretest mean 45.57 and Postest 66.17 with $p$ value 0.00 .

The mean difference before and after intervention using indoor + outdoor modules is pretest mean 45.90 and postest 73.7 with $p$ value 0.00 .

The mean difference of groups of students who received conventional modules 66.17 and indoor + outdoor modules 73.27 with $p$ value 0.00

\section{DISCUSSION}

The research conducted was experimental research using a "modelQuasi Experimental Design". This research was conducted on class X students as an experimental group and control group. Both of these classes are taught the same material, namely preparedness against volcanic eruptions. The treatment given to the two groups is different. The treatment given to the experimental group was learning using themethod Indoor + Outdoor learning, while the treatment in the control group was learning using themethod indoor learning. The experimental class is given prestest. The number of students who took the pretest was 30 students, and the control group was 30 students. The results of the pretest show. That all students in the experimental group and the control group received less scores. The student learning outcomes of the experimental group were better than the control group. The average posttest value of the experimental group students (73.27) was higher than the average value of the control group posttest (66.17).

Vol. XIV No. 1, Juni 2019

DOI: https://doi.org/10.32382/medkes.v14i1.708 
The learning process at school often leads to boredom in students. This is caused by the teaching and learning process that tends to be rigid and standard, not prioritizing the creativity ideas of each student because everything must be linear in the classroom (pedagogy indoor learning). Indoor learning alone causes learning saturation in students, so another approach used is Indoor + outdoor learning by applying a learning process that tends to be flexible, prioritizing creativity and initiative based on the students' reasoning power.

Hochrainer 2010, said that disasters can significantly reduce a country's economy. By using ARIMA analysis techniques on 225 events / events of natural disasters, it was concluded that within 5 years after the natural disaster, the economy slowly declined. Because disasters reduce the productivity of the production sectors.

According to Husamah (2013) said that outdoor learning provides a sense of freedom for students. The method of outdoor learning according to Husamah (2013) has an influence on student learning outcomes. As a result of not limiting students' thinking space by walls. In addition the outdoor learning method is a method of learning science by carrying out adventures in the surrounding environment accompanied by careful observation. These results cause learning to be more meaningful and also result in students being more motivated to learn.programs Outdoor learning provide an opportunity for students to actively engage in activities carried out. By being directly involved in activities students will immediately get feedback about the impact of these activities.

Adelia (2012) revealed that the advantages ofmethods outdoor learning can make the mind become clearer, learning feels more fun, variative, recreational, more real and the work of the brain becomes more relaxed.

\section{CONCLUSION}

Based on the results of the study concluded that there are differences in knowledge between students taught using conventional methods with students using methods indoor+ outdoor learning

\section{SUGGESTIONS}

1. It is expected that teaching indoor + outdoor methods can be developed as a variety of learning methods

2. Disaster preparedness needs to be developed in schools through educational curriculum development .

3. Students should routinely need to be given an understanding and skills about disaster preparedness for the surrounding community

\section{REFERENCES}

Adelia Vera. 2012. Teaching Methods for Children Outside the Class (Outdoor study). Yogyakarta: DIVA Press

2007 National Disaster Management Agency

David Alexander, Luca Bramati, Massimo Simonetta (2009) Emergency Preparedness Training and Education in Lombardy Region, Italy: Survey of Supply and Demand, Natural Hazards Review: 77-83.

Dharma, KK (2011) Nursing Research Methodology. Jakarta: Trans Media Info.

Hochrainer, Stefan (2010) Assessing The International Macroeconomic Impacts of Natural Disasters Institute of Applied System Analysis.

Husamah. (2013). Learning outside the outdoor learning class. Jakarta: Library Achievement.

Jane Miller (2014), Improving Emergency Preparedness System Readiness Through Simulation and Interprofessional Education, Public Health Reports: 129-135.

Margaret P (2010) The Evidence Base For Effectiveness of Preparedness Training: A Retrospective Analysis.

Noor D, (2006) Environmental Geology. Yogjakarta Graha Ilmu

Sugiyono (2010) Qualitative Kunatitative Research Methods and Bandung R \& D: Alfabeta

Law No.24 of 2007 concerningDisaster Management

Zakaria(2008) Geological Disaster Identification of Cianjur Regency, West Java Bulletin of Scientific Contribution Vol.6 No.1 August 2008 
Table 1 normality Test Data

\begin{tabular}{|c|c|c|}
\hline Description & $\mathrm{P}$ value & Interpretation \\
\hline Pre test control group & 0.100 & \multirow{4}{*}{$\begin{array}{l}P \text { value }>\text { a } 0: 05 \\
\text { distsributed the data } \\
\text { normally }\end{array}$} \\
\hline Post test control group & 0200 & \\
\hline Pretestintervention group & 0710 & \\
\hline Postintervention group test & 0097 & \\
\hline
\end{tabular}

table.2 Differences in scores before and after in the control group (Indoor module) in the city of Tomohon

\begin{tabular}{llll}
\hline & $\mathrm{N}$ & mean & P value \\
\hline PRE TEST & 30 & 45.57 & 0.001 \\
\hline POST TEST & 30 & 66.17 & \\
\hline
\end{tabular}

Table 3. Differences in scores before and after indoor and outdoor interventions in students in Tomohon City

\begin{tabular}{llll}
\hline & $\mathrm{n}$ & mean & P value \\
\hline PRE TEST & 30 & 45.90 & 0.001 \\
\cline { 1 - 3 } & 30 & 73.27 & \\
\hline
\end{tabular}

Table 4. Score in two receiving groups indoor modules with indoor-outdoor modules for students in Tomohon City

\begin{tabular}{|c|c|c|c|}
\hline & $\mathrm{N}$ & mean & $P$ values \\
\hline $\begin{array}{l}\text { Conventional Modules } \\
\text { (Controls) }\end{array}$ & 30 & 66.17 & 0.001 \\
\hline New Modules (Interventions) & 30 & 73.27 & \\
\hline
\end{tabular}

